\title{
National Health Security as an Effort to Increase Social Welfare: Challenges on Informal Sector Participants in Yogyakarta Special Region
}

\author{
Tria Anggita Hafsari \\ Research Center for Population \\ Research Center for Population
National Research and Innovation Agency \\ Jakarta, Indonesia \\ triaanggita01@gmail.com
}

\begin{abstract}
Health insurance ownership is one of the efforts to reduce poverty to achieve social welfare. Health insurance also becomes a social safety net in a labor market towards old-age benefits. Health security is one of the social protection that aims to support people in facing various stressors regarding health conditions. The Indonesia Government has created an effort to increase the coverage of health insurance membership by starting a Universal Health Coverage policy in 2004 through the National Health Insurance (JKN) program. However, this program faces many challenges, especially for the independent member participation in informal sector workers. Most informal sector workers could not afford the premium regularly, which causes their membership not to use it if they need it - this research focuses on informal sector workers. This paper aims to identify the factors influencing membership participation in the independent scheme (non-subsidy) in the JKN program. Data of this paper is based on research that combination of mix-match methods. The quantitative approach through surveys was conducted using purposive sampling. Meanwhile, qualitative data collection was carried out through interviews, focus group discussions, and observations. The results show 18.90 percent of respondents participated in the JKN program as independent scheme members. Several reasons cause the stagnant membership participation, such as economic factors related to the premium for all household members, feeling unnecessary to have health insurance, trust in the JKN program, and disappointment with health services used. Moreover, it is essential to ensure the informal sector workers can afford and access the JKN program as health security due to their vulnerabilities. Health security has become a requirement that is related to increasing the social welfare of citizens.
\end{abstract}

\author{
Sari Seftiani \\ Research Center for Population \\ National Research and Innovation Agency \\ Jakarta, Indonesia \\ sariseftiani27@gmail.com
}

Keywords-National Health Insurance (JKN), Membership participation, Informal sector workers, Social welfare, Yogyakarta Special Region

\section{INTRODUCTION}

Health security is one of the aspects that ensure the social welfare of people in a country. Social welfare can be defined as actions taken by humans to achieve a better life, not only from an economic perspective but also from social, psychological, and other aspects of spiritual life [1]. These human actions such as programs, benefits, and services aim to support people in regards to fulfilling their basic needs i.e. social, economic, education, and health [2]. In addition, Zastrow stated that social welfare aims to ensure all individuals and communities both rich and poor, can perform their social functions in society [3].

Social welfare becomes an issue for economic development. Economic growth is expected to contribute to the increase of standard of living in a country which influences the citizens who are living in the country. Economic growth has a two-way relationship with health. Economic development affects population health, whereas population health affects economic development. For instance, healthy people are related to the increase of productivity that can use for economic development. Through their productivity, it affects the increase of family income, which increases the Gross Domestic Product per Capita (GDP) in national aggregate. Also, the quality of human resources depends on their health.

In addition, ensuring a healthy life and improving welfare the people's well-being by achieving Universal Health Coverage (UHC) for all populations in the world is one of the Sustainable Development Goals (SDGs) [4]. There are several efforts to achieve the optimal UHC, namely (1) Protection against 
financial risks (for example: suffering from an illness or accident) for the entire community, (2) Access to quality health services for all communities (3) Access to safe, quality, and affordable treatment and immunization for all people [5]. Meanwhile, it needs support systems for the population towards better health and quality of life.

In Indonesia, the National Health Insurance (JKN) that provided by the government is one of the efforts to improve the wellbeing of Indonesian citizens. This program aims to provide health services and protection for all Indonesian citizens when they need medical treatments. It is stated on Constitution (Undang-Undang) Number 40, 2004 regarding the national social security system. JKN program has a target to achieve the UHC in Indonesia in 2030. In 2011, Social Insurance Administration Agency (BPJS) is formed by the government to manage the regulation and implementation systems through Law Number 24 in 2011. BPJS is starting in 2014 and has the vision to achieve the goal regarding health insurance for all people. However, the health insurance system in Indonesia tends to work slower compared to other Association of Southeast Asian Nations (ASEAN) countries [6].

Furthermore, there are three main subjects in JKN that are managed by BPJS such as membership, financing, and services. By January 1st, 2019, JKN membership reached around $82 \%$ or 215,8 million of Indonesia's population (Indonesia Ministry of Finance, 2019). Around 50 million people do not cover by JKN and the characteristics of that population group are not yet known. There are several reasons why some people prefer to not have health insurance especially JKN. Thabrany found that the nature of the Indonesians tends to stay in a risk condition on health and death events as God's destiny [6]. There is also an issue regarding the procedure and financial on implementation including the system in health care facilities. Therefore, it is important to include the local government to participate and support the central government in succeeding the UHC.

Based on research, the local government of Yogyakarta Special Region (DIY) is one of the provinces that support reaching the UHC goal. The two regions in DIY have a high percentage of membership in the JKN program. The percentage of JKN membership in Yogyakarta City is the amounts to $99.7 \%$. Almost all Yogyakarta residents are covered by the JKN program. Meanwhile, there is $95 \%$ of Bantul Regency Residents have covered by JKN. These facts realized that DIY becomes one of the provinces that reach the target of UHC that the central government has planned [7].

However, there are challenges in terms of reaching all DIY residents to cover the JKN program, especially for those who are working in the informal sector. JKN membership has two categories. First, Membership who are receiving the subsidy (PBI) and non-PBI or called "PBI-Mandiri". PBI scheme for those categorized as poor and underprivileged. The government gives the full subsidy for them. Meanwhile, those who are joining in Non-PBI scheme, have to afford the full premium without government subsidy.

Sector informal workers become one of the groups included in the non-PBI scheme that is classified as non-salary workers (PBPU). However, this group is one of the vulnerable groups due to the characteristics of their job. Informal sector workers are vulnerable in the economic aspects [8]. Their income is not stable and tends to work at risk because of the limitation in social security. Based on our research, there is $18.9 \%$ of non-PBI membership. This percentage shows that the coverage of membership from the informal sector remains deficient.

Sector informal worker is the most difficult group to join in the JKN program. It is because their jobs tend to be irregular and not permanent. On the other hand, informal sector workers are often not classified as poor although they have uncertain incomes, therefore, they cannot get the subsidy from the government. It causes the membership of the JKN program on the informal sector workers to often stop. Besides that, low literacy about the concept of health insurance also becomes a challenge to increase participation in the JKN program. According to our research, several reasons cause the problem in participation in the JKN program. This paper aims to describe the factors that become challenges to increasing the JKN membership of informal sector workers.

\section{METHODS}

Data on this paper is based on research about strengthening social protection to increase society's productivity in six provinces in Indonesia. The research was conducted by the Research Centre for Population-Indonesia Institute of Sciences in 2019. This paper only focuses on one province that is Yogyakarta Special Region (DIY). The research was performed by using a combination of qualitative and quantitative methods.

Qualitative data collection was carried out through in-depth interviews, focus group discussions with local government (district health offices, district planning development agency, medical staffs in community health centre, health social security agency) and local residents in DIY. Meanwhile, we conducted a survey and gray literatures (secondary data and official report related to Health National Security in DIY) to analyse the utilization of Health National Security (JKN) on informal sector workers and identify the problem of JKN. The survey used the 
purposive sampling method to collect data through face-to-face interviews. The survey was conducted on 279 respondents in DIY. There are 199 respondents in Yogyakarta City and 160 respondents in Bantul Regency. The research location and the number of respondents were based on the population who are working in the informal sector as the object of this research.

A thematic network analysis was used to analyse and interpret the resulting data to describe Health National Security (JKN) participation on informal sector workers in DIY.

\section{RESULTS AND DISCUSSION}

\section{A. Social Security in Indonesia}

The main purpose of development is to increase the welfare of citizens. Welfare can be measured from economic, social, cultural, and political dimensions [9]. The welfare is realized to ensure that every citizen can live properly and actualize their quality and capacity to carry out their social functions properly [10].

In Indonesia, social welfare wrote in Law Number 11, 2019 about social welfare in article 1 paragraph 1 stated social welfare is defined as a condition when all material, spiritual and social needs of citizens are fulfilled. Therefore, the citizens can live properly, develop themselves, and carry out their social functions. This law becomes a basis of the state to provide services for the Indonesian citizens in all aspects of life. The aim is to achieve material prosperity and create a better life in societies [1]. There are two main elements in the definition of social welfare. The first element is the existence of a service system for the community and the second one is an action to create a better standard of living for a person. According to the ILO [11], social protection is a part of a social policy intended to ensure access to social services for all, especially for vulnerable groups, and to protect and empower people in all life cycles. Asian Development argues that social protection is a policy and program designed to reduce poverty and vulnerability through efforts to increase and improve the population's capacity to protect themselves from disasters and loss of income [12]. Guhan views that social protection has broader components, including components of protection, prevention, and promotion [13]. In Indonesia, through Bappenas, the definition of social protection in all forms of public policies and interventions is carried out to respond to various physical, economic, and social risks and vulnerabilities, especially those experienced by those living in poverty [14].

Several studies showed that the availability of basic social protection for the poor can be carried out by every country, even by countries with a relatively low economic level [15]. In Indonesia, there is a tendency to alleviate poverty through empowering programs or even direct social assistance to the poor. Social assistance in the form of goods and money has also drawn criticism. According to Amartya Sen [16], the program is not designed to respond and reduce poverty, let alone uproot poverty. Instead, it only reduces vulnerability and suffering.

One of the practical steps in alleviating poverty is through health insurance. Also, personal health can increase economic productivity indirectly [17]. The government can intervene in improving the quality of human resources through health insurance programs. It is important and becomes a solution to reduce poverty because it is estimated that annually there are about 178 million people who cannot afford health care; 100 million of them fall into extreme poverty because they are forced to sell everything they have for medical treatment [18].

\section{B. National Health Security Program in Indonesia}

Social security in Indonesia has a long story. Starting in 1947, the Indonesian government has introduced social insurance [6]. However, providing health insurance is implemented in 1968 called "Asuransi Kesehatan" (Askes). At that time, Askes offered to civil servants (ASN) and retirees. Askes program was managed by the Health Care Fund Management Agency (BPDPK) that formed by regulation number 22 in 1984 . It aims to improve the health care provided by the health insurance program for the members; therefore, it became managed professionally.

The health security program is highly needed, especially for those vulnerable to their economic and social capabilities when they need health treatments. It is in line with the Constitution number 11, 2009 about Social Welfare that stated social protection aims to avoid and handle the risks from the stressors dan social vulnerability of individuals, families, and communities. Therefore, they can fulfill the basic needs of their daily life. Since 2004, the Indonesian government provides the JKN program to achieve social welfare for all citizens. This program has a target to cover all citizens in 2030. According to Indonesia Health Ministry, based on the Constitution number 40 in 2004 regarding National Social Security System (SJSN) and number 24 in 2011 regarding Social Insurance Administration Agency (BPJS), the success of the JKN program can be seen through to what extent this program is utilized.

Two things are highlighted in the JKN regulations, namely, the concept of JKN participation and financing. In the concept of JKN participation, every Indonesian citizen is required to become a JKN participant. So that every resident can be covered as a JKN participant. The membership regulations are made on a KK (family registers-based. When the head of the family is registered as a JKN participant, his family members automatically become JKN 
participants. Based on Presidential Regulation No. 12 of 2013, there are three categories of memberships, namely: (1) participant is any person, including foreigners who are working for a minimum of 6 months and have paid the premium in Indonesia; (2) employee is any person who works and receive salary or other payment forms; (3) employee is an individual or entrepreneur, a legal entity that employs workers or government employees by paying salaries, wages, or other forms.

Furthermore, there are two schemes based on the financing of JKN membership, i.e., PBI, for those who have received the subsidy from the government, and Non-PBI or "Mandiri" membership for participants who have to afford the premium. NonPBI is further divided into several criteria. The criteria are formal workers (PPU) such as civil servants and company employees; informal workers (PBPU) such as freelancers, hawkers, drivers; NonWorkers (BP) for example retirees.

The financing schemes are also different, for PBI contributions must be paid directly by the government each month through APBN or APBD funds, while PPU is deducted from their monthly salary. PBPU and BP are required to pay themselves through banks, cadres, or places that serve JKN contribution payments. . The amount of the monthly fee is divided into 3 clusters based on the maintenance service facilities as follows:

TABLE I. JKN CONTRIBUTION CATEGORY PER MONTH

\begin{tabular}{|l|l|}
\hline Treatment Room Class & $\begin{array}{c}\text { Amount of Contribution (in } \\
\text { Rupiah) }\end{array}$ \\
\hline Class I & $42.000^{1}$ \\
\hline Class II & 100.000 \\
\hline Class III & 150.000 \\
\hline
\end{tabular}

a. Source: https://bpjs-kesehatan.go.id/bpjs/index.php/pages/detail/2014/13

\section{Identification of JKN Membership in Yogyakarta}

Based on our survey, there are 83.87 percent were JKN participants, while another 16.13 percent (45 respondents) did not have JKN. categories that include trade, hotels, and restaurants dominated around 31.18 percent as the main occupation of the respondents in the informal sector. Moreover, there are 83.87 percent of respondents already had JKN. Most participants were in the PBI category, namely those who received subsidies from the government, both central and regional. Meanwhile, 18.9 percent are Non-subsidy (Non-PBI) participants. This percentage is not much different from the national participation condition, that is around 18 percent of the total population who have not yet BPJS Health participants [19]. The survey also indicated that the high participation rate because of the influence of the UHC program that the government is promoting.
Non-subsidy participants (Non-PBI), who do not reach 20 percent, need to be increased considering that there are already many participants who come from subsidy schemes. In this case, people who work in the informal sector become targets so that all residents are covered by health insurance.

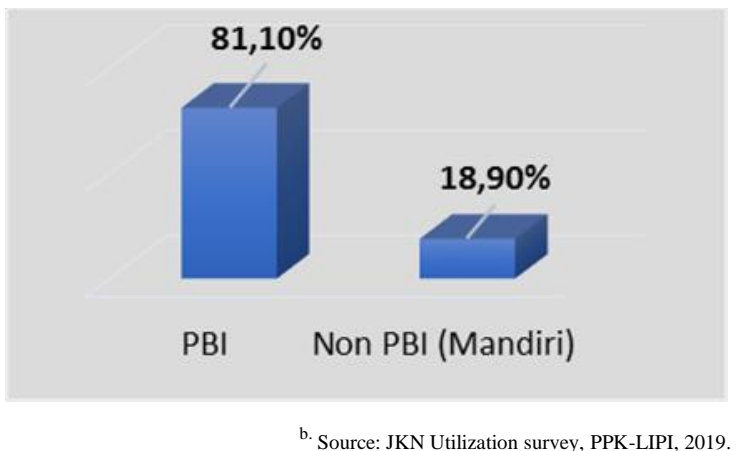

Fig. 1. The percentage of respondents by type of JKN participation

However, participation in Non-subsidy (Non-PBI) for informal sector workers is not that easy as participation in the formal sector. In the formal sector, the regulation requires companies to register its employees with JKN by the Ministry of Manpower and Transmigration has effectively increased BPJS Health membership. However, it does not apply to the informal sector workers. For residents who work in the informal sector, the government relies on residents' initiatives to register themselves as BPJS Health participants.

The informal sector is economically vulnerable because the status of the workforce is mainly in the form of temporary workers or family workers, and the employer-employee relationship is more of a personal connection and social relationship than an employment relationship with formal agreements or guarantees [13]. Based on the data survey (fig.2), most respondents are working in the trade, hotel, and restaurant sectors which reach the amount to 31.18 percent. Also, there is 17.92 percent work as service providers. This is related to the situation in DIY, which is known as a student city and a tourist city. Migrants play an important role in increasing the magnitude of these two job sectors. On the other hand, the agricultural and plantation sectors ( 12.54 percent) also need attention because workers in this sector tend to have low access to health services. Particularly in Bantul Regency, around 20 percent are working in the agriculture and plantation sectors. 


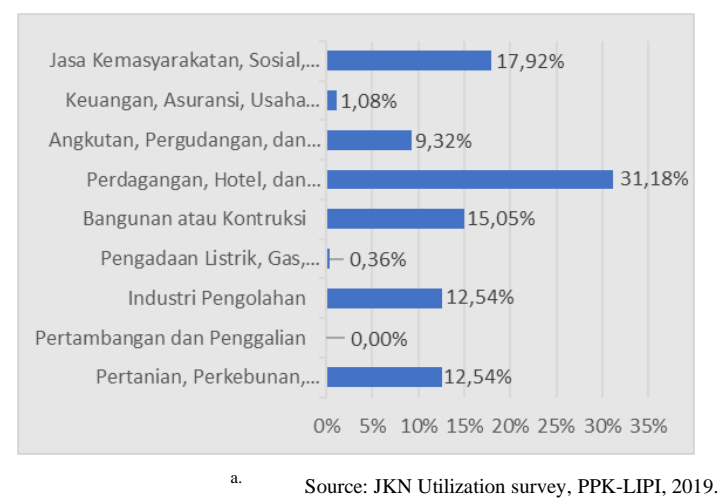

Fig. 2. the percentage of respondents by type of JKN participation

The unstable incomes of informal sector workers become a dilemma with a membership scheme policy based on the KK. With the KK-based participation model, the changes in the status of family members in the KK will impact other family members. The monthly JKN premium for the PBPU category includes all registered family members, not individually. However, if one family member is included in the PPU category, it will not be counted in the total contribution to be paid.

The data from the P2K-LIPI survey shows that the average household of DIY (Yogyakarta City and Bantul Regency) is four family members (including the head of the household). The survey also showed that 29.7 percent of respondents have four family members: father, mother, and two children. However, there is a household that has more than four family members. There can be 6-7 family members under one roof. Around $29(10.4 \%)$ respondents have family members more than four (6-7). The respondents are generally the sandwich generation who have burdens both from parents and children. It becomes a double burden for this generation, especially for those who are working in informal sectors which do not have stable incomes.

Table 2 (see in Appendix) shows the number of family members and how many family members have JKN. It can be seen that the majority of family members in one household are all registered as JKN participants.

As previously explained, DIY respondents generally amount to 4 people in one household $(83.3 \%)$. However, it should be noted that there is 87.5 percent of households have members of seven people and all of them have JKN. It can be calculated that the costs incurred to pay the monthly dues are Rp. 178,500 even though the average income is Rp.500.000 per month.

In line with the results of the focus group discussion that the participants from the Non-subsidy scheme, especially those who are working in the informal sector said that the cost for the premium every month is quite expensive because they have to pay for every household member. One of the informants revealed that it is difficult to afford the JKN premium for all household members. Whereas, he registered due to a health condition that needs prompt intervention.

There is an incomplete understanding regarding the obligation to have JKN in one household from a regulatory perspective. In terms of participation, JKN refers to the National Social Security System (SJSN) principles, namely the principles of cooperation, nonprofit, portability, mandatory participation according to ability, mandated funds, and the principles of managing Social Security Funds (Ministry of Health $\mathrm{RI}$ ). The principle of cooperation can be interpreted as cooperation (gotong-royong) from rich to poor. Then the non-profit principle emphasizes that this program does not aim to seek profit, contrary to meeting the interests of program participants.

In the PBPU participation scheme, participants are categorized as adequate. Some have difficulties paying the JKN premium every month. This gap makes the PBPU participant segment that the government's focus influences the sustainability of the JKN program. Informal sector workers who have unstable incomes affect the continuity of their JKN memberships as Non-Subsidy participants.

\section{Factors that influence the decision to become a JKN participant}

Although DIY can be said as one of the provinces that support the JKN program, especially in terms of membership, several challenges remain on this program. In general, three main problems that face in achieving the UHC in DIY, i.e., participant dues arrears, the regulation that changed rapidly, and health care conditions. These three problems influence the participation of the JKN program, especially for informal sector workers who are paid the premium independently.

Sector informal workers have a propensity to be in arrears the premium of the JKN. It is because they do not have a stable income that causes difficulties to afford regularly. Likewise, the scheme of premium in the JKN program is based on family registration (Kartu Keluarga). Therefore, the membership of JKN should pay the whole premium for the family who is registered. This condition affects the payment of the JKN premium. For informal sector workers who do not have a stable income, it isn't easy to afford the premium regularly for all household members.

\section{1) The membership-based on the family card (family based-registration)}

At first, the JKN membership scheme was for individuals, and this is regulated in BPJS Regulation No. 4 of 2014. Within one year, the regulation was changed to KK-based. It is stated in BPJS Regulation 
No. 1 of 2015. This new regulation regulates the procedure for registration and payment of dues. This makes it more difficult for PBPU participants who have unstable incomes. This condition is related to the poverty line and cannot be registered as PBI participants. The focus group discussions noted that if there were arrears on behalf of one participant, all family members were blocked. This means that all family members who did not take advantage of the previous JKN will be blocked when they use health facilities until the arrears are paid. Moreover, research also found that the informant remains bears the participants' contributions who have died. The existence of a mismatch in population administration issues makes participants reluctant to continue their contributions and is considered to be in arrears.

TABLE II. POVERTY LEVEL DATA AND HEALTH INSURANCE OWNERSHIP

\begin{tabular}{|c|c|c|c|c|c|c|}
\hline \multirow{3}{*}{$\begin{array}{c}\text { Based on the } \\
\text { DIY poverty } \\
\text { line, Rp. } \\
353,684 \\
(\text { March/2019) } \\
\end{array}$} & \multicolumn{6}{|c|}{ Type of ownership of the health social security of the head of the household } \\
\hline & \multicolumn{2}{|c|}{ PBI } & \multicolumn{2}{|c|}{ Mandiri } & \multicolumn{2}{|c|}{ Don't have health insurance } \\
\hline & total & percentage & total & percentage & total & percentage \\
\hline Miskin & 120 & 63,15 & 14 & 31,81 & 13 & 28,88 \\
\hline Tidak Miskin & 70 & 36,84 & 30 & 68,18 & 32 & 71,11 \\
\hline Total & 190 & 100 & 44 & 100 & 45 & 100 \\
\hline
\end{tabular}

Informal sector workers who have income is close to the poverty line face a dilemma regarding access to health facilities. The arrears premium must be repaid first, and these arrears are the total cost of all family members. The problem is getting harder when the arrears have occurred for one year and the number of family members is four people. In Yogyakarta, there are still informal sector workers who are classified as poor. Table 3 . This shows 14 respondents are included in the poor category, but the type of participation is Non-subsidy (Non-PBI)

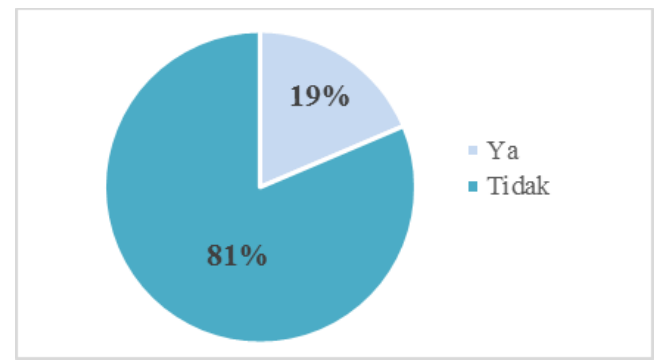

Fig. 3. The percentage of Non-PBI membership who have experienced the arrears of membership dues

c. Source: JKN Utilization survey, PPK-LIPI, 2019.

Figure 1 shows the percentage of residents that experiencing the arrears of membership dues in the Yogyakarta Special Region (DIY). Of the 44 residents categorized as Non-PBI membership, 19\% of participants could not afford the premium. It reveals that there are participants who face difficulties affording the regular compensation of JKN. Research also found that the reason this situation occurred is the perception of participants that JKN only when they are sick or need treatment from health facilities. Therefore they think that it is not a must to afford the JKN premium regularly. The participants will pay the arrears of dues when they have to get the treatments from health facilities that need more money, such as childbirth and surgery due to chronic diseases. Besides that, some people do not understand the concept of gotong royong in the JKN program. This concept means that healthy people contribute to paying for sick people. Even though the participants do not feel ill, they should pay the JKN premium. The perception of paying for other people who are sick leads to actions to postpone the payment of JKN premium because they think that they are becoming inactive participants. There are no term passive participants, both PBI and Non-PBI, according to BPJS Kesehatan. People who have been registered in the JKN program are active membership for life. However, those participants who do not pay the regular premium within a month cannot access the health facilities for free. It also affects the capitation value related to first-level health facilities (FKTP). Meanwhile, JKN memberships must keep going. It has become the reason that causes the participant to be in arrears.

\section{2) JKN premium contribution problem}

As previously mentioned, informal sector workers are a vulnerable group from an economic point of view. The type of work and income that changes are the reasons why this group is susceptible. The regulations in the JKN membership and financing scheme are quite confusing in some ways. This is the finding of researchers in the FGD conducted in Yogyakarta. Some of the causes include:

- Some people used to be PBI and then became PPU, but now that they are not working, they are confused about their JKN membership payment scheme 
- A construction worker registers his wife and children in an independent scheme, currently experiencing problems in continuing to pay dues so that now, the arrears in contributions are pretty large

- There is also a mother who used to be part of the PBI scheme. Then became a contract employee at the tourism office and received JKN (she did not do any arrangements, transfers, etc.), but she was confused about the financing because she is no longer working and wanted to give birth. He does not know whether the JKN-PBI that he used to have has been deactivated to become independent or what.

Several examples of cases found in the field became a dilemma for the community to continue their participation in the JKN program. In addition, the case affects other communities that have not been registered in the JKN program. This is in line with the news that the PBPU segment is the most difficult to capture. This is because there is a dilemma related to regulations in the PBPU participant segment, especially for workers whose income is not fixed and their jobs often change.

The results of the KDP-LIPI survey show that many informal sector workers in Yogyakarta are temporary workers. 66.7 percent of respondents work in the trade, hotel, and restaurant sectors, with the status of their businesses assisted by temporary workers (see table 4 in appendix). Following the case found, if he is a worker whose income is above the poverty line, he cannot pay contributions after he does not get a job, but his status is still considered able to bear? In the future, it is hoped that there will be regulations that can protect these vulnerable groups so that the achievement of Universal Health Coverage can be realized immediately and for the community itself to feel optimal benefits from this JKN program

\section{3) The lack of health care facilities}

Research also found that the reason behind the participant's dues arrears problem is related to the health services that experienced by the member. Based on focus group discussion in two regions in DIY, that is Yogyakarta City and Bantul Regency, this research identified that there are many complaints from the memberships of the JKN program regarding the health services such as long queue at the Puskesmas, basic drugs, and tiered referral system. The JKN program participants often wait for a long time when they need treatments at Puskesmas or a hospital that cooperates with BPJS. The participants said that the premium is not comparable with time to queue. Moreover, the regulation related to tiered referral system at the first level health facilities (FKTP) become a challenge for the participants who live in density areas because they cannot choose the empty of FKTP. Participants also said that they cannot access another FKTP because they already registered at the FKTP which is determined by BPJS. Likewise, when the participants need to refer to the hospital due to their health condition, they have to pass through their FKTP.

According to BPJS, the situation regarding the procedures to the hospital is common occurred. However, BPJS claimed that this procedure aims to distribute access to health services for all citizens. It is because the participants often access the health services based on their preferences. Also, the tiered referrals system has already been used since the health insurance Askes program exists. These regulations are only modified according to the current conditions.

\section{4) Lack of knowledge about health insurance}

The arrears and the case examples discussed earlier show a gap between the understanding of the community and the government. Mandatory participation means that all Indonesians without exception have health insurance. Compulsory health insurance is intended so that all people get protection for their health aspects. A healthy society affects the productivity of the community. And for the poor can still get health services without being caught up in the high costs they have to spend when using health facilities. This is then translated into the principle of gotong royong, the rich helping the poor. This is also stated in the Regulation of the Minister of Health Number 28 of 2014 that although participation is mandatory, its application is still adjusted to the people and the government's economic capacity and the feasibility of implementing the program.

However, the reality on the ground is that several cases make it difficult for the community. Instead of being guaranteed their health, economically difficult people have become more complicated with various regulations. This gap occurs because of the public's ignorance of the JKN program participation and financing scheme. So, when something like the above occurs, they are confused about how to find solutions. So that for some people, the JKN program adds to the burden of their life responsibilities economically.

Thabrany, in his book, firmly criticizes that the most significant cause of death in Indonesia is government policy. Is the program helping the poor to seek treatment as long as it fulfills development planning commitments? Or do you want to eradicate poverty through a health insurance program for the poor? Because according to him, if we only prevent the poor from getting poorer, we don't consider the possibility that the non-poor can fall into poverty due to an illness. As happened in the case that the researchers found, in the past, when working, they were included in the category of being able to pay contributions when not working, and there was no 
monthly income. However, they still had to pay monthly dues. According to Thabrany, everyone has the right to receive health services according to their needs, not on their economic capacity.

\section{CONCLUSION}

Informal sector workers are the most challenging group in regards to participating in the JKN program. The first reason is that the unstable incomes and do not have other social security. This sector is categorized as a vulnerable group, especially for those who have income close to the poverty line. For informal sector workers, the new regulation regarding the premium scheme that covers all the family members becomes a new burden. Most of the participants that experience arrears, feel confused about their membership status when they are unemployed, and cannot afford to pay their monthly dues.

The second reason is regarding the health facilities. the regulation that related to tiered referral system and long queue at the health care facilities including in Puskesmas as the first level of health facilities (FKTP) in implementation. The last one is regarding the lack of health insurance knowledge. It is related to the mindset of people that health insurance is needed when they are sick. Therefore, when they are feeling well, they think that having health insurance is not necessary.

Based on these problems, it is needed to ensure the criteria of Non-subsidy (Non-PBI) participants, especially for informal sectors. The unstable incomes make their economic condition are vulnerable. The local government needs to support them regarding the premium. In this situation, the contribution of the government is highly needed to help the sector informal workers especially those who are on the poverty line. Regarding the knowledge of insurance, it is important to socialize massively to make people have a better understanding of the purpose of health insurance.

\section{REFERENCES}

[1] Adi, I. R. (2018) Kesejahteraan Sosial: Pekerjaan Sosial, Pembangunan Sosial, dan Kajian Pembangunan. Depok: Rajawali Press.

[2] Barker, R. L. (2003) The Social Work Dictionary, 5th Ed Wangshinton, DC: NASW Press.
[3] Zastrow, C. 2010. Introduction to Social work and Social Welfare: Empowering People, 10th Edition. Brook/Cole: USA.

[4] United Nations. 2016. The Sustainable Development Goals Report 2016. New York: United Nations. Retrieved from https://unstats.un.org/sdgs/report/2016/The\%20Sustainable \%20Development\%20Goals\%20Report\%202016.pdf

[5] Agyepong, I. A. (2018). Universal health coverage: breakthrough or great white elephant? The Lancet, 392(10160), 2229-2236. https://doi.org/10.1016/S01406736(18)32402-4

[6] Thabrany, Hasbullah. 2014. Jaminan Kesehatan Nasional Jakarta : PT Raja Grafindo Persada.

[7] Dinas Kesehatan DIY. 2019. Data Kepesertaan BPJS Kesehatan

[8] Sparrow, R., Poel, E. Van De, Hadiwidjaja, G., Yumna, A., Warda, N., \& Suryahadi, A. 2014. Coping with the Economic Consequences of Ill Health in Indonesia. Health Economics, 23, 719-728. http://doi.org/10.1002/h

[9] Widyastuti, Astriana (2012). Analisis hubungan antara produktivitas pekerja dan tingkat pendidikan pekerja terhadap kesejahteraan keluarga di Jawa Tengah tahun 2009. Economics Development Analysis Journal 1 (1) (2012).

[10] Segel \& Bruzy. 1998. Pengertian kesejahteraan sosial, Jakarta.

[11] International Labour Organization. (2012). Penilaian Landasan Perlindungan Sosial Berdasarkan Dialog. Jakarta: ILO

[12] Habibullah, Habibullah. (2017). Perlindungan Sosial Komprehensif Di Indonesia. Sosio Informa, 3(1), 1-14. https://doi.org/10.33007/inf.v3i1.492

[13] Guhan, S. (1994). Social Security Options for Developing Countries. International Labor Review, 133, hal. 35-53. In Brunori, P. \& O'Reilly, M. (2010). Social Protection for Development: A Review of Definitions. European Report on Development.

[14] Supriyanto, R. W., Ramdhani, E. R., \& Rahmadan, E. (2014). Social protection in Indonesia: Challenges and Future. In Bappenas.

[15] Suharto, E. (2011). Social Protection for Children. December, 1-17

[16] Sen, Amartya ad James Wolfensohn. (2004). Helping Disabled People Out of The Shadows in the Jakarta Post, December 03

[17] Suharto, Edi. (2103). Kemiskinan dan Perlindungan Sosial di Indonesia: Menggagas Model Jaminan Sosial Universal Bidang Kesehatan. Alfabeta: Bandung

[18] Wieczorek-Zeul, Heidemarie. (2005). Social Health Insurance in Development Cooperation. In Jens Holst and Assia Brandrup Lukanow (eds), Extending Social Protection in Health: Developin Countries Experiences, Lesson Learnt and Recomendations, Frankurt: VAS, pg.1-2

[19] Kementerian Keuangan. 2019. Pembiayaan yang Berkelanjutan untuk Jaminan Kesehatan Nasional (JKN) Menuju Pelayanan Kesehatan Semesta (UHC) di Indonesia. Jakarta. 